Article

\title{
Does Anthropogenic Land Use Change Play a Role in Changes of Precipitation Frequency and Intensity over the Loess Plateau of China?
}

\author{
Zhengjia Liu $1,2,3, * \mathbb{D}$ and Yansui Liu ${ }^{1,3, *}$ \\ 1 Institute of Geographic Sciences and Natural Resources Research, Chinese Academy of Sciences, \\ Beijing 100101, China \\ 2 State Key Laboratory of Remote Sensing Science, Institute of Remote Sensing and Digital Earth, \\ Chinese Academy of Sciences, Beijing 100101, China \\ 3 College of Resources and Environment, University of Chinese Academy of Sciences, Beijing 100049, China \\ * Correspondence: 1zj7sdjn@126.com (Z.L.); liuys@igsnrr.ac.cn (Y.L.); Tel.: +86-186-1261-2470 (Z.L.)
}

Received: 13 September 2018; Accepted: 15 November 2018; Published: 16 November 2018

check for updates

\begin{abstract}
Human transformation of landscapes is pervasive and accelerating across the Earth. However, existing studies have not provided a comprehensive picture of how precipitation frequency and intensity respond to vegetation cover change. Therefore, this study took the Loess Plateau as a typical example, and used satellite-based Normalized Difference Vegetation Index (NDVI) data and daily gridded climatic variables to assess the responses of precipitation dynamics to human-induced vegetation cover change. Results showed that the total precipitation amount exhibited little change at the regional scale, showing an upward but statistically insignificant $(p>0.05)$ trend of $7.6 \mathrm{~mm} /$ decade in the period 1982-2015. However, the frequency of precipitation with different intensities showed large variations over most of the Loess Plateau. The number of rainy days (light, moderate, heavy, very heavy and severe precipitation) increased in response to increased vegetation cover, especially in the central-eastern Loess Plateau. Anthropogenic land cover change is largely responsible for precipitation intensity changes. Additionally, this study also observed high spatially explicit heterogeneity in different precipitation intensities in response to vegetation cover change across the Loess Plateau. These findings provide some reference information for our understanding of precipitation frequency and intensity changes in response to regional vegetation cover change in the Loess Plateau.
\end{abstract}

Keywords: land use and land cover change; precipitation; remote sensing; afforestation; The Loess Plateau

\section{Introduction}

Human transformation of landscapes is pervasive and is accelerating across the Earth [1-4]. Human activities have also strongly contributed, at least from the second half of the 19th century, to global warming and to its consequences. In 2000, the term 'Anthropocene' was introduced just to denote the present epoch, in which many conditions and processes of the Earth have been altered by human activities, as well as to guide scientists and engineers toward environmentally sustainable management $[4,5]$. In this context, it is important to better understand and quantify the anthropogenic contributions to climatic and environmental changes. Especially, some typical case analyses are more likely to improve our understanding of the effects of human activities on the climatic and environmental changes. 
The Loess Plateau, one of China's four plateaus, together with the Tibetan Plateau, the Inner Mongolia Plateau and the Yun-Gui Plateau, is one of the most ecologically fragile regions in the world. Unreasonable land use and severe soil erosion have limited the regional sustainable development of the Loess Plateau and worsened its environment [6-10]. Since the year of 1999, the 'Grain for Green' (also regarded as 'conversion from slope croplands to forests or grasslands') project was carried out, which evidently led to reductions in the area of slope croplands and the amount of soil erosion by means of revegetation (e.g., afforestation and natural restoration) in the Loess Plateau [11,12]. Comparing land use maps in 2000 and 2015, past satellite-based studies showed that the net amount of cultivated land dropped across the entire Loess Plateau over the last 15 years $[13,14]$. Large-area afforestation was shown to reduce runoff of the Loess Plateau due to increased evapotranspiration demand $[15,16]$. Annual runoff observed data from the Tongguan station showed that annual sediment load decreased from 1.6 billion tons per year (average in 1950-1960) to less than 0.3 billion tons per year (average in 2000-2010) [12]. Increased vegetation cover plays the primary role in decreased soil erosion and increased evapotranspiration $[8,11]$. Similar to most regions of the world, vegetation greening trends are widely observed in the Loess Plateau over the past decade [17-19]. Earlier studies report that climate change, land management, carbon dioxide concentration increase, and dry and wet atmospheric depositions of nitrogen are regarded as the main reasons of vegetation greening trends at the global and regional scales [18-20]. A previous study of ours showed that human activities contributed more to the increase of vegetation cover in the Loess Plateau than climatic and other factors [18]. In the context of climate change, extreme events are increasing worldwide [21-26], and the Loess Plateau does not constitute an exception. Recently, extreme precipitation events in some regions of the Loess Plateau, such as extreme precipitation events in Yan'an city (in July 2013) and Suide county of Yulin city (on 26 July 2017 and in August 2018) [27,28] have severely threatened the safety of local people's life and property. However, whether human activities have potential relationships with these phenomena is still unknown.

In recent years, vegetation cover change in the Loess Plateau has attracted high attention, especially within the ecological and remote sensing communities $[8,17,18,29,30]$. Many previous studies have focused on the biological and hydrological effects of vegetation cover change $[8,30,31]$. For example, Ouyang et al. (2016) reported that human-induced vegetation cover increase promoted ecosystem services of the Loess Plateau, especially in carbon sequestration and soil conservation. Fu et al. (2017) reported that increased vegetation cover reduced both runoff and sediment load from the Loess Plateau. These studies have improved our understanding on how vegetation cover change impacts carbon cycle, runoff and soil conservation. Additionally, there are some studies paying more attention to the causes of vegetation cover change. For example, studies from Sun et al. (2015) and Cao et al. (2018) employed long-term satellite-based Normalized Difference Vegetation Index (NDVI) to investigate the impacts of human activities and climate change on vegetation cover change and stated that human activities and climate change (precipitation and temperature changes) evidently increased vegetation cover. However, the biophysical effects induced by increased vegetation cover, in particular, the impact of vegetation cover change on precipitation, still remain poorly understood [32,33]. Recent studies have discussed the regulating effect of vegetation cover change on the regional temperature [33,34], but the effects on regional precipitation have rarely been reported. Some studies indicate that precipitation response to vegetation cover change is often ignored by observation-based analyses [16,24]. Currently, there is rarely a clear and comprehensive picture of the relationship between precipitation dynamics and vegetation cover change, especially when different precipitation frequency and intensity are taken into account. This limits our understanding of the interaction between precipitation and vegetation cover changes.

Therefore, the objectives of this study are (1) to analyze land use and land cover change (LUCC) over the past three decades and its corresponding driving factors; (2) to investigate long-term (1982-2015) precipitation frequency and intensity changes; and (3) to clarify the relationships between precipitation frequency/intensity changes and LUCC; and attempt to explain their potential reasons. 


\section{Materials and Methods}

\subsection{Study Area}

The Loess Plateau is located in northern China, covering an area of $\sim 62.4 \times 10^{4} \mathrm{~km}^{2}$. There are 108 million people living in the Loess Plateau [11]. The region is primarily dominated by a semi-arid continental monsoon climate with annual mean air temperature ranging from 0 to $13^{\circ} \mathrm{C}$ and annual mean precipitation gradually decreasing from $\sim 700 \mathrm{~mm}$ in the southeast to $\sim 50 \mathrm{~mm}$ in the northwestern Loess Plateau [35]. The study area includes six natural zones, and these are: (I) the Loess gully region; (II) the irrigation region; (III) the sand and desert regions; (IV) the Loess hilly and gully regions; (V) the valley plain region and (VI) the earth-rock mountain region (Figure 1).

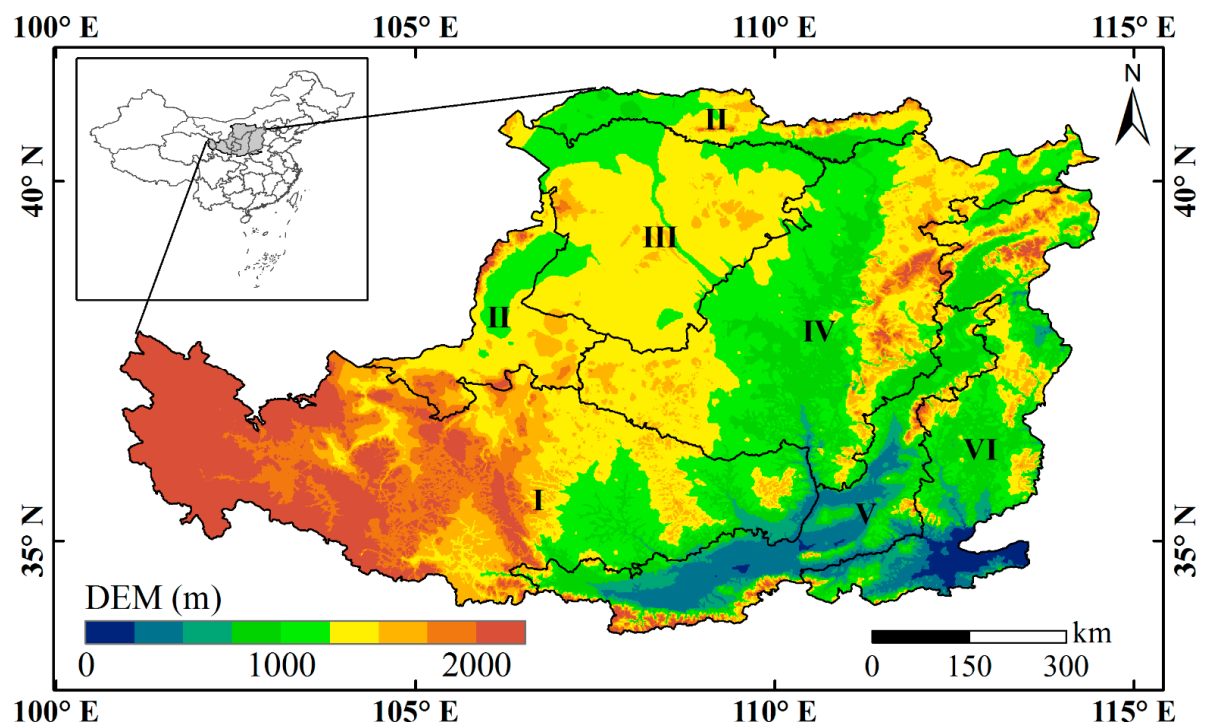

Figure 1. Location of the Loess Plateau and its digital elevation model (DEM). The Loess Plateau covers six natural zones, including (I) the Loess gully region; (II) the irrigation region; (III) the sand and desert regions; (IV) the Loess hilly and gully regions; (V) the valley plain region and (VI) the earth-rock mountain region.

\subsection{Data and Processing}

Data used in this study covered the third-generation Global Inventory Modeling and Mapping Studies (GIMMS3g) NDVI, daily gridded climatic variables (precipitation, air temperature and solar radiation), land use and land cover data and the digital elevation model (DEM).

The 15-day GIMMS3g NDVI data with the 1/12-degree spatial resolution, covering the 1982-2015 period, were collected from NASA Earth Exchange (NEX). GIMMS3g NDVI data were assembled from different AVHRR sensors onboard several NOAA satellites. Corrections were made to harmonize the different sensors and physical conditions, including the effects of latitudinal variations and calibration loss in the solar zenith angles due to volcanic eruptions and orbital drift [36]. The data were widely used to investigate global environmental changes [37-39]. Certainly, the noise induced by cloud contamination and poor atmospheric conditions is inevitable in remote sensing data. Previous studies have suggested that the modified Savitzky-Golay (mSG) filter has more robust ability in reconstructing a high-quality NDVI [40,41]. To allow more accurate assessment of vegetation cover change, this study first used the $\mathrm{mSG}$ filter with smoothing window size of $2 \mathrm{~m}+1(\mathrm{~m}$ is a parameter here, and $\mathrm{m}=4)$ and quartic polynomial to smooth all GIMMS3g NDVI data [37]. By using the maximum value composite technique [42], 15-day GIMMS3g NDVI were then aggregated to monthly data, as shown in the following equation.

$$
\mathrm{NDVI}_{i}=\max \left(\mathrm{NDVI}_{a i}, \mathrm{NDVI}_{b i}\right)
$$


where, $\mathrm{NDVI}_{i}$ is the $i$ th month NDVI; NDVI $a i$ and $\mathrm{NDVI}_{b i}$ represent NDVI in the first half and the second half of $i$ th month, respectively. Finally, based on monthly NDVI and the maximum value composite technique, this study obtained maximum NDVI of each year. Annual maximum NDVI values were used in the final analyses.

Daily gridded precipitation and temperature data with the resolution of $0.25^{\circ}$ longitude by $0.25^{\circ}$ latitude for the period of 1982-2015 were collected form National Meteorological Administration of China (CMA). The gridded data were derived from the records of 2416 meteorological stations (termed as CN05.1) [43]. Thin-plate smoothing splines (ANUSPLIN, a widely used meteorological interpolation technique) method [44], as well as DEM, as the covariate was used for the gridded interpolation [24]. The detailed steps of interpolation are described in some previous references [43,45]. The number of the observed stations of CN05.1 data is significantly greater than the 751 freely shared basic meteorological stations. Theoretically, CN05.1 data thus have a more robust performance due to employing a larger number of meteorological stations, and therefore they were used in the present study. Daily gridded ERA-interim solar radiation data were collected form the European Centre for Medium-Range Weather Forecasts (ECMWF) [46]. To match the spatial resolution of GIMMS3g NDVI, the datasets of daily climatic factors were first interpolated into 1/12 degree by using the ANUSPLIN method in combination with NASA Shuttle Radar Topographic Mission (SRTM) DEM as the concomitant variation.

The 1-km spatial resolution land use data in 1990, 2000 and 2010 derived from Landsat TM/ETM+, OLI and HJ-1 sensors were collected from Data Center for Resources and Environmental Sciences, Chinese Academy of Sciences [13]. These datasets and related methods were widely used for related studies of China's land use [13,47-51].

\subsection{Statistical Analyses}

The overlay analysis, allowing users to perform an analysis of multiple inputs, was used to investigate land use change in two different periods (1990-1999 and 2000-2010).

By using the pixel-based residual analysis method, human-induced NDVI was separated from satellite-based NDVI [18]. Specifically, the equation is listed as follows [52].

$$
\mathrm{NDVI}_{r}=\mathrm{NDVI}-\mathrm{NDVI}_{c}
$$

where $\mathrm{NDVI}_{r}, \mathrm{NDVI}$ and $\mathrm{NDVI}_{c}$ are human-induced NDVI, satellite-based NDVI and climate-based NDVI, respectively. Please note that estimation of $\mathrm{NDVI}_{c}$ plays the most important role in the above equation. Thus, this study first computed contributions of climatic variables on NDVI. As our recent study stated [18], this study also separated the entire period into two key periods (before and after the year 1999) in view of large-area applications of ecological engineering (the 'Grain for Green' project) since 1999 in the study area. By using satellite-based NDVI and assembled climatic variables for the period of 1982-1999 at the pixel scale, the study introduced the climate-based NDVI model, as Equation (3) shows. A recent study [18] reported that the assembled climatic variables could make the climate-based NDVI model more robust. Thus, by using the methods of Liu et al. (2018), this study calculated the assembled monthly temperature $\left(T_{a}\right)$, assembled monthly precipitation $\left(P_{a}\right)$ and assembled monthly solar radiation $\left(R_{a}\right)$.

$$
\mathrm{NDVI}_{c}=p_{0}+p_{1} T_{a}+p_{2} P_{a}+p_{3} R_{a}
$$

where, $p_{0}, p_{1}, p_{2}$ and $p_{3}$ are the regression coefficients. Specifically, this study employed the least square method to derive the regression coefficients of each pixel with the help of Matlab tools [18,37]. In addition, then, this study used these regression coefficients obtained from the period of 1982-1999, as well as the assembled monthly climatic variables in 2000-2015 to compute annual climate-based NDVI in the second period after the year 1999. Finally, based on the annual satellite-based NDVI 
and annual climate-based NDVI for the period of 2000-2015, human-induced NDVI of each year was derived according to Equation (2).

A frequency analysis was used to count days with different precipitation intensities in each year. Traditionally, light, moderate, heavy, very heavy and severe precipitation are defined as daily precipitation amounts greater than $0.1,10,25,50$ and $100 \mathrm{~mm}$, respectively (Table 1). In particular, heavy, very heavy and severe precipitation are usually regarded as extreme events [53,54]. The Theil-Sen estimator, which is a robust trend analysis method based on non-parametric statistics [55,56], was used to spatially compute the precipitation trend for each intensity category. The significance is computed by using the Mann-Kendall nonparametric statistical method [35]. A significant difference is attained when the observed $p$-value is less than 0.05 (the significance level). Conversely, when the $p$-value is greater than 0.05 , the difference is of no statistical significance. The Pearson correlation (r) was used to explain the relationships of different precipitation intensities and LUCC. The corresponding significant difference $(p<0.05)$ was also computed based on the nonparametric statistical method.

Table 1. Classifications of precipitation intensities and their corresponding daily precipitation amount $\left(\mathrm{P}_{24 h}\right)$.

\begin{tabular}{cc}
\hline Classification & Daily Precipitation Amount $(\mathbf{m m})$ \\
\hline No precipitation & $\mathrm{P}_{24 \mathrm{~h}}<0.1$ \\
Light precipitation & $0.1 \leq \mathrm{P}_{24 \mathrm{~h}}<10$ \\
Moderate precipitation & $10 \leq \mathrm{P}_{24 \mathrm{~h}}<25$ \\
Heavy precipitation & $25 \leq \mathrm{P}_{24 \mathrm{~h}}<50$ \\
Very heavy precipitation & $50 \leq \mathrm{P}_{24 \mathrm{~h}}<100$ \\
Severe precipitation & $\mathrm{P}_{24 \mathrm{~h}} \geq 100$ \\
\hline
\end{tabular}

\section{Results}

\subsection{Land Use Change and Its Major Driving Factors}

Figure 2 shows the major land use changes, with the overall change area being greater than $0.5 \%$ of the entire study area during the period 1990-1999 and the period of 2000-2010. Before the year 2000, the increase in croplands $(+0.29 \%$ of all pixels, and similarly thereafter) and urban and built-up land $(+0.15 \%)$, and the decrease in barren or sparsely vegetated $(-0.2 \%)$, grasslands $(-0.16 \%)$, forests $(-0.04 \%)$ and water bodies $(-0.04 \%)$ were major land use changes in the Loess Plateau. Particularly, conversion from grasslands to croplands was the major land use change type in the Loess Plateau, accounting for $0.67 \%$ of entire study area. These were mainly located in Ningxia Province of western Loess Plateau. Certainly, there were also some small-area conversions from grasslands to croplands scattered across the entire Loess Plateau. After the year 2000, larger land use changes were observed across the entire Loess Plateau, but these land use conversions were very fragmented (Figure $2 b$ ). The increase in forests $(+0.71 \%)$ and urban and built-up land $(+0.50 \%)$ and the decrease in croplands $(-0.71 \%)$, barren or sparsely vegetated lands $(-0.32 \%)$, and grasslands $(-0.22 \%)$ were major land use dynamics in the Loess Plateau. Specifically, in the land use dynamic process, conversion from croplands to grasslands and conversion from grasslands to croplands were major land use change types, accounting for $1.52 \%$ and $1.51 \%$ of the entire study area, respectively. The second were conversion from grasslands to forests, conversion from barren or sparsely vegetated lands to grasslands, and conversion from croplands to forests, accounting for $0.74 \%, 0.73 \%$ and $0.57 \%$, respectively. One can see that land conservation dominated land use dynamics in the context of the 'Grain for Green' project [11,57]. In addition, there are also some regions with grassland degeneration $(0.47 \%$, mainly located in the northwestern Loess Plateau; the Mu Us Sandy Land). Please note that urban expansion mainly occupied croplands around urban and build-up land $(0.40 \%)$. 


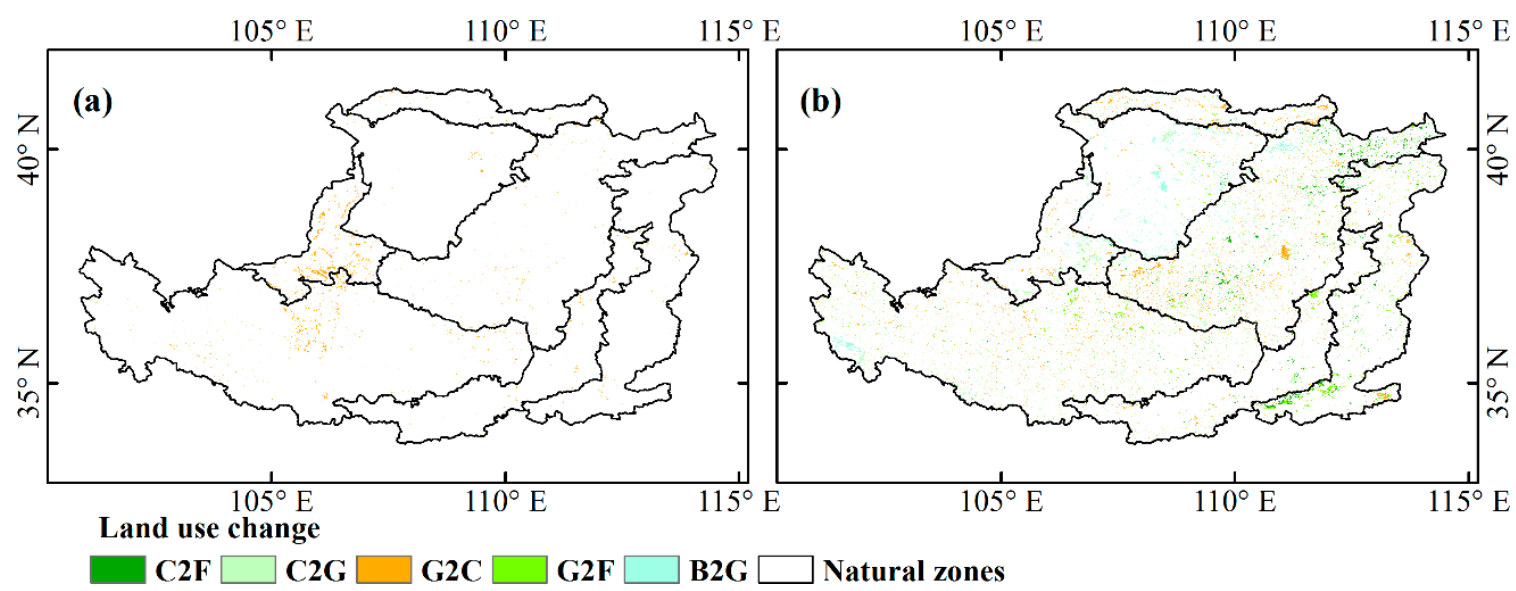

Figure 2. Major land use changes, with overall change area being greater than $0.5 \%$ of the entire study area during the periods 1990-1999 (a) and 2000-2010 (b). C2F represents conversion from croplands to forests; $\mathrm{C} 2 \mathrm{G}$ represents conversion from croplands to grasslands; $\mathrm{G} 2 \mathrm{C}$ represents conversion from grasslands to croplands; G2F represents conversion from grasslands to forests; and B2G represents conversion from barren or sparsely vegetated land to grasslands.

\subsection{Anthropogenic Contributions to Land Cover Change}

To clarify the contributions of anthropogenic land use change, we used a climate-based NDVI model to derive climate-based NDVI. Figure $3 a-g$ show the long-term trends of satellite-based NDVI and climate-based NDVI in six different natural zones and entire Loess Plateau. For the entire Loess Plateau (Figure 3g), satellite-based NDVI presented a very significant upward trend, with a slope of 0.022 /decade during the period 1982-2015 $(p<0.05)$. However, a significant trend was not observed in the climate-based NDVI, which only showed a very weak upward trend, with a slope of $0.001 /$ decade for the corresponding period $(p>0.05)$. It is worth noting that the change curves of satellite-based NDVI and climate-based NDVI showed a large difference after 2006, suggesting that anthropogenic contributions started to have good effects for the increase of vegetation cover. Similarly, in six natural zones, anthropogenic contributions all showed positive effects for the increase of vegetation cover, but satellite-based NDVI and climate-based NDVI exhibited different trends. Trends of climate-based NDVI in six natural zones turned out to be statistically insignificant $(p>0.05)$. Also, we noted that the irrigation region, the sand and desert regions and the earth-rock mountain region even showed negative trends, with slopes of $-0.005 /$ decade, $-0.004 /$ decade, and $-0.0004 /$ decade, respectively $(p>0.05)$. In contrast, the satellite-based NDVI of six natural zones all displayed very significant upward trends $(p<0.05)$. Among them, the increased trend of satellite-based NDVI in the loess hilly and gully regions $(0.036 /$ decade, $p<0.05)$ was evidently greater than those in the other five regions. Particularly, anthropogenic contributions in the Loess hilly and gully regions made NDVI increase by $\sim 0.15$ over the last five years. The valley plain region displayed the weakest upward trend, with a slope of $0.011 /$ decade $(p<0.05)$, and the lowest anthropogenic contribution to the increase of NDVI $(<0.05)$. 


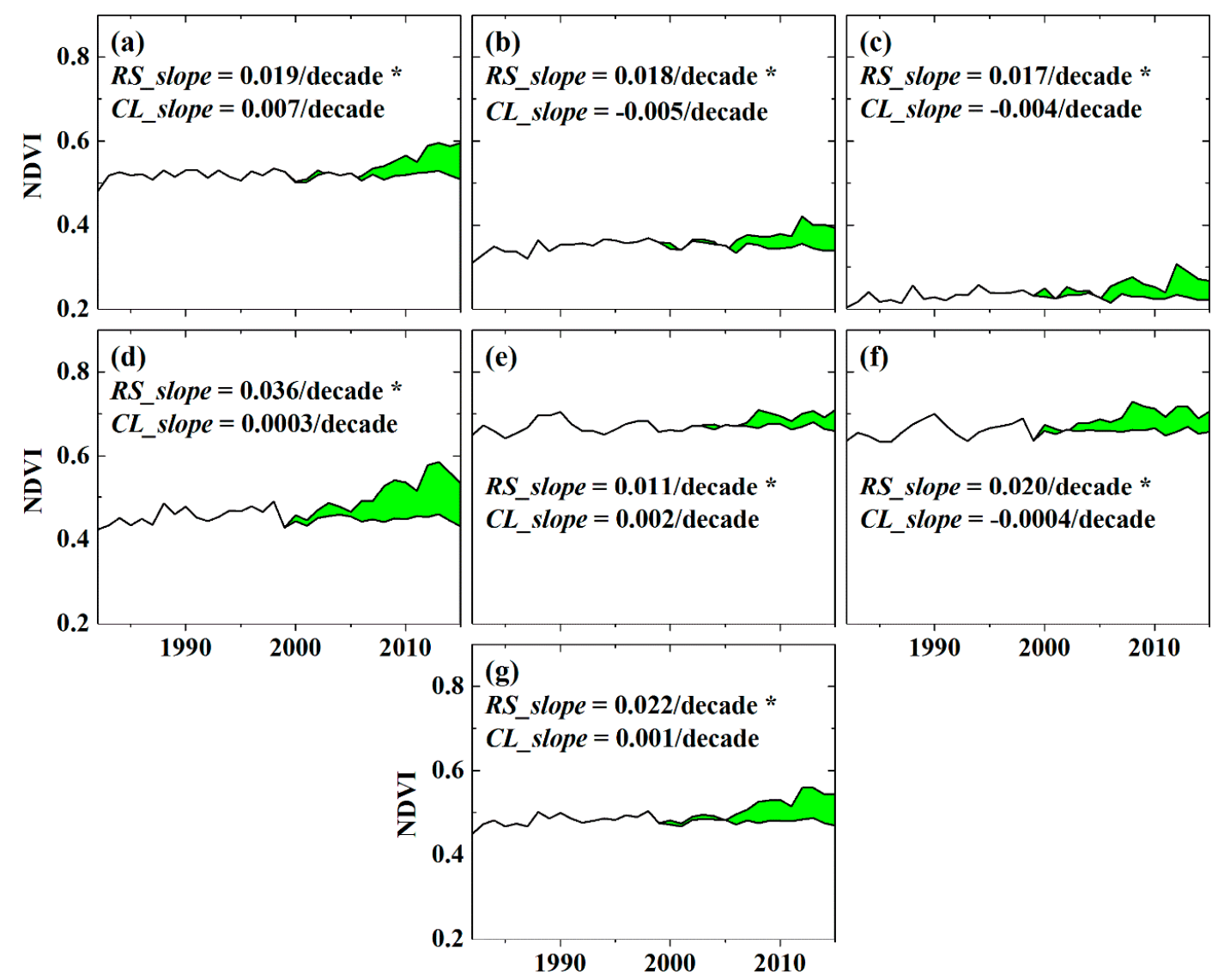

Figure 3. Trends of satellite-based observed NDVI (RS) and climate-derived NDVI (CL) during the period 1982-2015. Green shaded area represents human-induced NDVI, of which subfigures (a) the Loess gully region; (b) the irrigation region; (c) the sand and desert regions; (d) the Loess hilly and gully regions; (e) the valley plain region; (f) the earth-rock mountain region and (g) entire Loess Plateau present trends of RS and CL NDVI in each corresponding region, respectively. The symbol * represents the significance at the $95 \%$ statistical level $(p<0.05)$.

\subsection{Frequency Changes of Different Precipitation Intensities}

In the past three decades, averaged annual precipitation of the entire Loess Plateau was $420 \pm 50 \mathrm{~mm}$, and annual precipitation remained a relatively stable trend (slope of $7.6 \mathrm{~mm} /$ decade, $\mathrm{R}^{2}=0.03, p>0.05$ ). Yet annual fluctuations in precipitation were evidently observed. The total precipitation amount had little change at the regional scale, but the frequency of different precipitation intensities and spatially distinct patterns showed large variations. Figure 4 shows spatially distinct distributions, long-term trends and the corresponding significance of different precipitation intensities. Days of no precipitation (or, to be more precise, with daily precipitation lower than $0.1 \mathrm{~mm}$ ) gradually increased from the southern and eastern ( 170 days) to the northwestern Loess Plateau ( 250 days). In the southern and northwestern Loess Plateau, days of no precipitation exhibited significantly increased trends, with slopes greater than $\sim 10$ days/decade $(p<0.05)$. However, a significantly decreasing trend was observed in most regions of the eastern Loess Plateau. Please note that the decreasing trend was greater than 10 days/decade $(p<0.05)$ in some regions of the Loess hilly and gully regions. In contrast, light precipitation with a daily precipitation amount ranging from 0.1 to $10 \mathrm{~mm}$ exhibited the opposite spatially distinct patterns and trends to no precipitation. Moderate precipitation, heavy precipitation, very heavy precipitation and severe precipitation all exhibited decreased days from the southeastern to the northwestern Loess Plateau, but their corresponding trends evidently exhibited spatial differences. It is worth noting that increased days of different precipitation intensities were mostly observed in the central-eastern Loess Plateau. For example, 
moderate precipitation showed significantly increased days in the central Loess hilly and gully regions of the Loess Plateau, with trends of 1 days/decade $(p<0.05)$. Heavy precipitation showed increased days in the eastern Loess gully region and the western earth-rock mountain region of the Loess Plateau, with trends of 5 days /100a (100a represents a hundred years in this study). Very heavy precipitation, defined as daily precipitation ranging from 50 to $100 \mathrm{~mm}$, showed increased days in the central Loess Plateau, with trends of 5 days/100a. This represents an increase in days of severe precipitation of 1 day /100a, but most of these were not significant at the 0.05 statistical level.

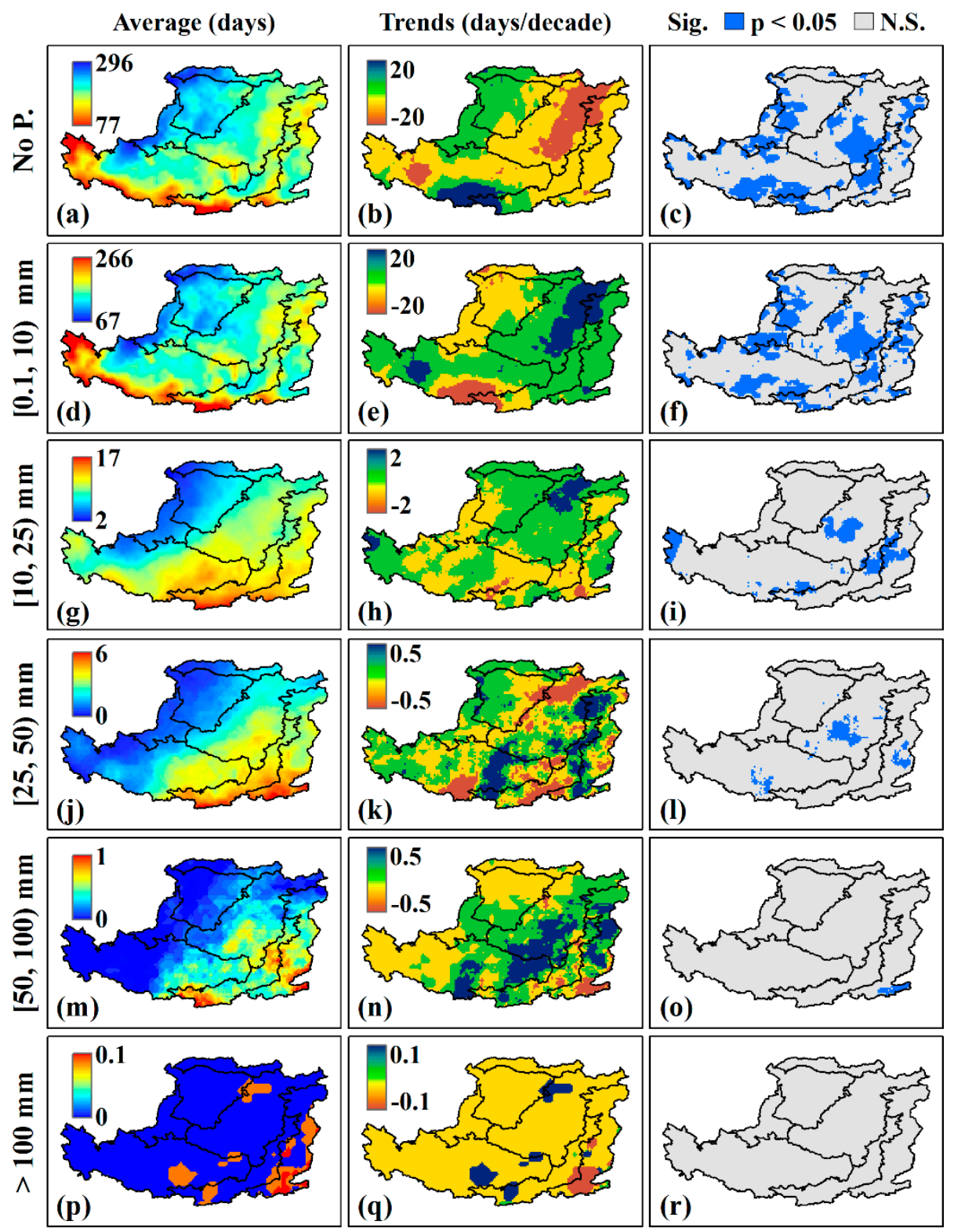

Figure 4. Changes of different precipitation (P.) intensities during the period 1982-2015. (a-c) No P. is no precipitation (or, to be more precise, daily precipitation lower than $0.1 \mathrm{~mm}) ;(\mathbf{d}-\mathbf{f})$ daily precipitation ranging $[0.1,10) \mathrm{mm}$ represents light precipitation; $(\mathbf{g}-\mathbf{i})$ daily precipitation ranging $[10,25) \mathrm{mm}$ represents moderate precipitation; $(j-1)$ daily precipitation ranging $[25,50) \mathrm{mm}$ represents heavy precipitation; $(\mathbf{m}-\mathbf{o})$ daily precipitation ranging $[50,100) \mathrm{mm}$ represents very heavy precipitation; and (p-r) daily precipitation greater than $100 \mathrm{~mm}$ represent severe precipitation, respectively. Sig. is the significance level, and N.S. is no significance at the 0.05 statistical level. 


\subsection{Relationships between Precipitation Intensity Changes and LUCC}

This study further investigated the correlations between different precipitation intensity changes and human-induced land cover change (Figure 5). Days of no precipitation and NDVImax were significantly correlated in $45.5 \%$ of regions of the Loess Plateau $(p<0.05)$, of which $37.8 \%$ of regions showed significant negative correlations, with $\mathrm{r}$ values of $-0.485 \pm 0.089(p<0.05)$, and $7.7 \%$ of regions significant positive correlations, with $r$ values of $0.493 \pm 0.103(p<0.05)$. In contrast, days of light precipitation and NDVImax exhibited the opposite correlation patterns. $33.0 \%$ of regions showed significant positive correlations, with $\mathrm{r}$ values of $0.470 \pm 0.084(p<0.05)$, and $9.0 \%$ of regions showed significant negative correlations, with $r$ values of $-0.493 \pm 0.104(p<0.05)$. Significant positive correlations between days of moderate precipitation and NDVImax, with $r$ values of $0.443 \pm 0.077$ $(p<0.05)$, were mainly found in the northern and southwestern Loess Plateau, accounting for $20.0 \%$ of all pixels. Significant positive correlations between days of heavy precipitation and NDVImax, with $r$ values of $0.415 \pm 0.060$ ( $p<0.05)$, were mainly found in the central Loess Plateau, accounting for $12.8 \%$ of all pixels. Compared to the first four correlations, Figure $5 \mathrm{e}, \mathrm{f}$ also show relatively high $\mathrm{r}$, with values of $0.409 \pm 0.067$ and $0.404 \pm 0.045$ ( $p<0.05)$, but only in relatively small-area regions, accounting for $6.4 \%$ for very heavy precipitation and $0.9 \%$ for severe precipitation.
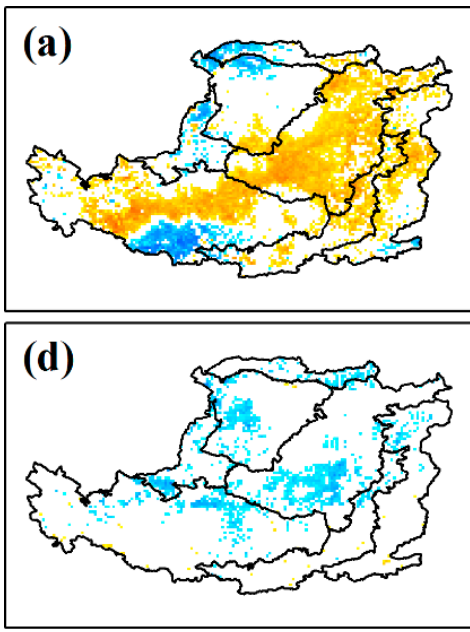
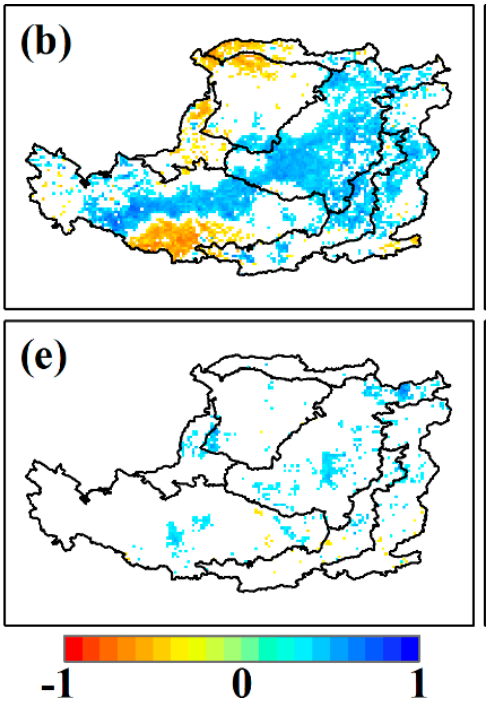
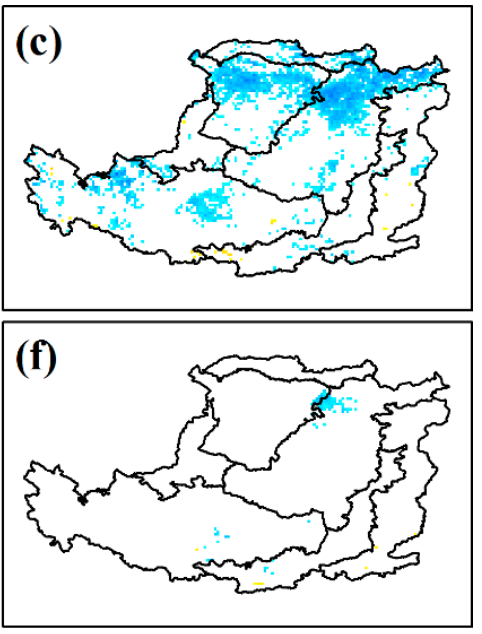

Figure 5. Correlations between different precipitation intensity changes and land cover change during the period 1982-2015. (a) No precipitation; (b) light precipitation; (c) moderate precipitation; (d) heavy precipitation; (e) very heavy precipitation; (f) severe precipitation. Please note that all sub-figures only show significant correlations at the 0.05 statistical level.

\section{Discussion}

\subsection{Precipitation in Relation to Warming Air and Increasing Evapotranspiration}

The warming global air temperature could widen land-sea thermal contrast, and further enhance general atmospheric circulation $[58,59]$. This could speed up the water cycle at the global and regional scale, and could alter precipitation patterns and trends [54]. Warming air temperatures could improve the ability of the atmosphere to store water [60,61]. IPCC reports indicate that if the air temperature increases by $1{ }^{\circ} \mathrm{C}$, the ability of the atmosphere to store water will likely increase by $\sim 5 \%$. Therefore, warming climate could increase either precipitation frequency or precipitation intensity, or perhaps both. In addition to the impact of the general atmospheric circulation, our study suggests that increased evapotranspiration induced by increased vegetation cover is also responsible for changes of precipitation patterns and trends. Previous studies have consistently indicated that increased vegetation cover evidently increases the amount of evapotranspiration, although the impacts of human-induced 
vegetation cover change on soil moisture dynamics in the Loess Plateau are still disputed [15,16,62]. It is undeniable that increased evapotranspiration induced by high vegetation cover makes a substantial contribution to the increase of water vapor in the atmosphere. In theory, water phase change from land surface water to atmospheric water vapor needs to soak up abundant heat from the surrounding air. When humid air rises to the condensation level, water vapor starts to condense into droplets or ice crystals, and also forms clouds. In the process of cloud formation, water phase change from water vapor to droplets or ice crystals can release heat, which warms the surrounding air. At the same time, warming air can rise again. The aforementioned processes are repeated again. The repeated processes provide more energy for the formation of extreme precipitation events. Certainly, if there is not enough humid air supply, the aforementioned processes will be significantly weakened. Conversely, however, increased evapotranspiration induced by high vegetation cover provides sufficient humid air supply $[16,32,63]$. Therefore, increased evapotranspiration induced by high vegetation cover, along with warming air temperature, could drive the formation of extreme precipitation events, to some extent.

\subsection{Interactions between Land Cover Change and Precipitation Dynamics}

Our analyses highlight that anthropogenic contributions dominate the significant upward trends of NDVI compared to climatic contributions. In the Loess Plateau, the 'Grain for Green' project has played an important role in the increase of forests and the decrease of slope croplands. Land conservation policies have allowed more local people to transfer abundant cultivated land from some regions with a slope greater than $25^{\circ}$ to the nearby gentle slope regions and valleys. These land use policies and ecological engineering approaches are mainly responsible for the land greening in this region.

Previous studies have focused more on the responses of vegetation cover change to precipitation dynamics and the impacts of climate change on precipitation [16,20,64]. Distinct from these studies, our study investigates the relationships between different precipitation intensity changes and vegetation cover change, and highlights the analysis of the impact of vegetation cover change on precipitation dynamics. This study observes that annual precipitation amount of the entire Loess Plateau remains a relatively stable or weak increased trend in the fluctuations, with a slope of $7.6 \mathrm{~mm} /$ decade $\left(R^{2}=0.03\right.$, $p>0.05)$, suggesting a weak impact of vegetation cover change on annual total precipitation amount. Interestingly, this finding is also confirmed by a previous model-based study, which reports that increased vegetation cover change and increase forest area have an insignificantly positive effect on precipitation of North China [16]. However, it is worth noting that our study finds that human-induced vegetation cover change significantly alters precipitation frequency in most of the Loess Plateau, although there are some differences with regard to different precipitation intensities in various regions. Vegetation cover change regulating the regional hydrological cycle is likely responsible for this phenomenon $[8,16]$. These findings could greatly enrich our understanding of interactions between vegetation cover change and precipitation dynamics in the Loess Plateau.

\subsection{Importance and Limitations of This Study}

An expanded 'Grain for Green' project could be an effective way of reducing soil erosion and carbon dioxide emission $[6,8,11]$. Yet, the findings of our study suggest that we should consider the biophysical feedback of abundant revegetation (especially in the feedback of precipitation dynamics), thereby maximizing ecological, climatic and socio-economical service values. From this viewpoint, the findings of this study could have crucial policy implications. As previous studies have stated, continued expansion of revegetation could cause more harm than good to communities and environments $[6,11]$.

Certainly, there are some limitations to this study. For example, the study only investigates the impacts of human-induced land surface vegetation cover change on precipitation intensity and frequency changes. It is undeniable that the distance from the sea, topography, general atmospheric circulation, atmospheric pressure, wind zone, monsoon, ocean current, greenhouse gases and aerosol 
change also play very important roles in regulating precipitation dynamics at global and regional scales. As we know, precipitation is a complex process. Further studies need to comprehensively consider precipitation intensity and frequency changes in response to more driving factors. They will also be valuable for understanding the non-linear relationships and feedbacks between vegetation and precipitation. In addition, precipitation feedbacks from vegetation greening may have altered precipitation, either locally or remotely, in downwind regions. However, this study only presents the feedback at the pixel scale. Thus, a regional- or larger-scale study could further improve our understanding for the feedbacks between precipitation and vegetation greening in depth. Also, a series of more comprehensive and process-based modeling studies are highly imperative, and will help us deeply understand the mechanism in the impacts of LUCC on precipitation events.

\section{Conclusions}

Satellite-based data can greatly assist in the monitoring of large-area anthropogenic landscape changes, and in analyzing the effects of human activities on climatic and environmental changes. In this study, by using GIMMS3g NDVI data and daily gridded precipitation, the potential responses of precipitation dynamics to human-induced vegetation cover change in the Loess Plateau were investigated. The present study showed that precipitation frequency is increasing in most of the Loess Plateau. In most regions with revegetation, significant negative correlations between days of no precipitation and NDVImax suggest that increased vegetation cover was largely responsible for the precipitation frequency change. Significant positive correlations between increased vegetation cover and increased light, moderate, heavy, very heavy, severe precipitation were spatially observed, and their corresponding areas accounted for $33 \%, 20 \%, 12.8 \%, 6.4 \%$ and $1 \%$ of the entire Loess Plateau, respectively. These findings highlight that anthropogenic land use change is largely responsible for changes of precipitation frequency and intensity over the Loess Plateau. This study only provides some preliminary findings, which could be, however, helpful for improving our understanding of precipitation frequency and intensity change in response to regional vegetation cover change in the Loess Plateau. Importantly, these findings could provide some valuable information for decision makers in sectors of watershed management, agricultural management and disaster prevention. Furthermore, these preliminary findings also imply that further studies with the help of global/regional climate models, as well as dynamic vegetation models, will be very useful in improving our understanding of the biophysical effects of regional vegetation cover change.

Author Contributions: Z.L. designed and wrote this manuscript. Z.L. and Y.L. revised this manuscript together.

Funding: This work was funded by the National Key Research and Development Program of China [Grant No. 2017YFC0504701], the National Natural Science Foundation of China [Grant No. 41601582] and the Start-up Research Program of IGSNRR funding to Z. Liu.

Acknowledgments: We are grateful for GIMMS3g NDVI, CMA and ERA-Interim data, CAS land use data and SRTM DEM. We also appreciate Xiaoyue Wang for providing an IDL-based Mann-Kendall nonparametric statistical method. Besides, special thanks will be given to three anonymous reviewers and editors for their valuable suggestions and comments, which evidently improved this manuscript.

Conflicts of Interest: The authors declare no conflict of interest.

\section{References}

1. Ellis, E.C.; Ramankutty, N. Putting people in the map: Anthropogenic biomes of the world. Front. Ecol. Environ. 2008, 6, 439-447. [CrossRef]

2. Ellis, E.C.; Kaplan, J.O.; Fuller, D.Q.; Vavrus, S.; Klein Goldewijk, K.; Verburg, P.H. Used planet: A global history. Proc. Natl. Acad. Sci. USA 2013, 110, 7978-7985. [CrossRef] [PubMed]

3. Ellis, E.C. Ecology in an anthropogenic biosphere. Ecol. Monogr. 2015, 85, 287-331. [CrossRef]

4. Crutzen, P.J. Geology of mankind. Nature 2002, 415, 23. [CrossRef] [PubMed]

5. Smith, B.D.; Zeder, M.A. The onset of the Anthropocene. Anthropocene 2013, 4, 8-13. [CrossRef] 
6. Chen, Y.; Wang, K.; Lin, Y.; Shi, W.; Song, Y.; He, X. Balancing green and grain trade. Nat. Geosci. 2015, 8, 739-741. [CrossRef]

7. Liu, Y.; Guo, Y.; Li, Y.; Li, Y. GIS-based effect assessment of soil erosion before and after gully land consolidation: A case study of Wangjiagou project region, Loess Plateau. Chin. Geogr. Sci. 2015, 25, 137-146. [CrossRef]

8. Fu, B.; Wang, S.; Liu, Y.; Liu, J.; Liang, W.; Miao, C. Hydrogeomorphic Ecosystem Responses to Natural and Anthropogenic Changes in the Loess Plateau of China. Annu. Rev. Earth Planet. Sci. 2017, 45, 223-243. [CrossRef]

9. Li, Z.; Zhang, G.; Geng, R.; Wang, H.; Zhang, X. Land use impacts on soil detachment capacity by overland flow in the Loess Plateau, China. Catena 2015, 124, 9-17. [CrossRef]

10. Li, Z.; Zhang, G.; Geng, R.; Wang, H. Spatial heterogeneity of soil detachment capacity by overland flow at a hillslope with ephemeral gullies on the Loess Plateau. Geomorphology 2015, 248, 264-272. [CrossRef]

11. Feng, X.; Fu, B.; Piao, S.; Wang, S.; Ciais, P.; Zeng, Z.; Lü, Y.; Zeng, Y.; Li, Y.; Jiang, X.; et al. Revegetation in China's Loess Plateau is approaching sustainable water resource limits. Nat. Clim. Chang. 2016, 6, 1019-1022. [CrossRef]

12. Wang, S.; Fu, B.; Piao, S.; Lü, Y.; Ciais, P.; Feng, X.; Wang, Y. Reduced sediment transport in the Yellow River due to anthropogenic changes. Nat. Geosci. 2015, 9, 38-41. [CrossRef]

13. Liu, J.; Kuang, W.; Zhang, Z.; Xu, X.; Qin, Y.; Ning, J.; Zhou, W.; Zhang, S.; Li, R.; Yan, C.; et al. Spatiotemporal characteristics, patterns, and causes of land-use changes in China since the late 1980s. J. Geogr. Sci. 2014, 24, 195-210. [CrossRef]

14. Ning, J.; Liu, J.; Kuang, W.; Xu, X.; Zhang, S.; Yan, C.; Li, R.; Wu, S.; Hu, Y.; Du, G.; et al. Spatiotemporal patterns and characteristics of land-use change in China during 2010-2015. J. Geogr. Sci. 2018, 28, 547-562. [CrossRef]

15. Feng, X.; Cheng, W.; Fu, B.; Lü, Y. The role of climatic and anthropogenic stresses on long-term runoff reduction from the Loess Plateau, China. Sci. Total Environ. 2016, 571, 688-698. [CrossRef] [PubMed]

16. Li, Y.; Piao, S.; Li, L.Z.X.; Chen, A.; Wang, X.; Ciais, P.; Huang, L.; Lian, X.; Peng, S.; Zeng, Z.; et al. Divergent hydrological response to large-scale afforestation and vegetation greening in China. Sci. Adv. 2018, 4, eaar4182. [CrossRef] [PubMed]

17. Cao, Z.; Li, Y.; Liu, Y.; Chen, Y.; Wang, Y. When and where did the Loess Plateau turn "green"? Analysis of the tendency and breakpoints of the normalized difference vegetation index. Land Degrad. Dev. 2018, 29, 162-175. [CrossRef]

18. Liu, Z.; Liu, Y.; Li, Y. Anthropogenic contributions dominate trends of vegetation cover change over the farming-pastoral ecotone of northern China. Ecol. Indic. 2018, 95, 370-378. [CrossRef]

19. Zhu, Z.; Piao, S.; Myneni, R.B.; Huang, M.; Zeng, Z.; Canadell, J.G.; Ciais, P.; Sitch, S.; Friedlingstein, P.; Arneth, A.; et al. Greening of the Earth and its drivers. Nat. Clim. Chang. 2016, 6, 791-795. [CrossRef]

20. Leroux, L.; Bégué, A.; Lo Seen, D.; Jolivot, A.; Kayitakire, F. Driving forces of recent vegetation changes in the Sahel: Lessons learned from regional and local level analyses. Remote Sens. Environ. 2017, 191, 38-54. [CrossRef]

21. Cui, L.; Wang, L.; Qu, S.; Singh, R.P.; Lai, Z.; Yao, R. Spatiotemporal extremes of temperature and precipitation during 1960-2015 in the Yangtze River Basin (China) and impacts on vegetation dynamics. Theor. Appl. Clim. 2018, 134, 1-18. [CrossRef]

22. Najafi, M.R.; Moazami, S. Trends in total precipitation and magnitude-frequency of extreme precipitation in Iran, 1969-2009. Int. J. Climatol. 2016, 36, 1863-1872. [CrossRef]

23. Kharin, V.V.; Zwiers, F.W.; Zhang, X.; Wehner, M. Changes in temperature and precipitation extremes in the CMIP5 ensemble. Clim. Chang. 2013, 119, 345-357. [CrossRef]

24. Liu, Z.; Liu, Y.; Wang, S.; Yang, X.; Wang, L.; Baig, M.H.A.; Chi, W.; Wang, Z. Evaluation of spatial and temporal performances of ERA-Interim precipitation and temperature in Mainland China. J. Clim. 2018, 31, 4347-4365. [CrossRef]

25. Fay, P.A.; Kaufman, D.M.; Nippert, J.B.; Carlisle, J.D.; Harper, C.W. Changes in grassland ecosystem function due to extreme rainfall events: Implications for responses to climate change. Glob. Chang. Biol. 2008, 14, 1600-1608. [CrossRef] 
26. Li, Z.; Xu, X.; Xu, C.; Liu, M.; Wang, K.; Yu, B. Annual runoff is highly linked to precipitation extremes in Karst catchments of Southwest China. J. Hydrometeorol. 2017, 18, 2745-2759. [CrossRef]

27. Sun, W.; Tian, Y.; Mu, X.; Zhai, J.; Gao, P.; Zhao, G. Loess Landslide Inventory Map Based on GF-1 Satellite Imagery. Remote Sens. 2017, 9, 314. [CrossRef]

28. Wang, G.; Li, T.; Xing, X.; Zou, Y. Research on loess flow-slides induced by rainfall in July 2013 in Yan'an, NW China. Environ. Earth Sci. 2015, 73, 7933-7944. [CrossRef]

29. Sun, W.; Song, X.; Mu, X.; Gao, P.; Wang, F.; Zhao, G. Spatiotemporal vegetation cover variations associated with climate change and ecological restoration in the Loess Plateau. Agric. For. Meteorol. 2015, 209-210, 87-99. [CrossRef]

30. Ouyang, Z.; Zheng, H.; Xiao, Y.; Polasky, S.; Liu, J.; Xu, W.; Wang, Q.; Zhang, L.; Xiao, Y.; Rao, E. Improvements in ecosystem services from investments in natural capital. Science 2016, 352, 1455-1459. [CrossRef] [PubMed]

31. Zhai, J.; Liu, R.; Liu, J.; Huang, L.; Qin, Y. Human-Induced Landcover Changes Drive a Diminution of Land Surface Albedo in the Loess Plateau (China). Remote Sens. 2015, 7, 2926-2941. [CrossRef]

32. Xiao, J. Satellite evidence for significant biophysical consequences of the "Grain for Green" Program on the Loess Plateau in China. J. Geophys. Res. 2014, 119, 2261-2275. [CrossRef]

33. Liu, Z.; Liu, Y.; Baig, M.H.A. Biophysical effect of conversion from croplands to grasslands in water-limited temperate regions of China. Sci. Total Environ. 2019, 648, 315-324. [CrossRef] [PubMed]

34. Peng, S.; Piao, S.; Zeng, Z.; Ciais, P.; Zhou, L.; Li, L.Z.X.; Myneni, R.B.; Yin, Y.; Zeng, H. Afforestation in China cools local land surface temperature. Proc. Natl. Acad. Sci. USA 2014, 111, 2915-2919. [CrossRef] [PubMed]

35. Liu, Z.; Liu, Y.; Li, Y. Extended warm temperate zone and opportunities for cropping system change in the Loess Plateau of China. Int. J. Climatol. 2018, 38, 1-12. [CrossRef]

36. Pinzon, J.; Tucker, C. A Non-Stationary 1981-2012 AVHRR NDVI3g time series. Remote Sens. 2014, 6, 6929-6960. [CrossRef]

37. Wang, S.; Mo, X.; Liu, Z.; Baig, M.H.A.; Chi, W. Understanding long-term (1982-2013) patterns and trends in winter wheat spring green-up date over the North China Plain. Int. J. Appl. Earth Obs. 2017, 57, 235-244. [CrossRef]

38. Garonna, I.; de Jong, R.; Schaepman, M.E. Variability and evolution of global land surface phenology over the past three decades (1982-2012). Glob. Chang. Biol. 2016, 22, 1456-1468. [CrossRef] [PubMed]

39. Zhu, Z.; Bi, J.; Pan, Y.; Ganguly, S.; Anav, A.; Xu, L.; Samanta, A.; Piao, S.; Nemani, R.R.; Myneni, R.B. Global data sets of vegetation leaf area index (LAI) $3 \mathrm{~g}$ and Fraction of Photosynthetically Active Radiation (FPAR) $3 g$ derived from Global Inventory Modeling and Mapping Studies (GIMMS) Normalized Difference Vegetation Index (NDVI3g) for the period 1981 to 2011. Remote Sens. 2013, 5, 927-948.

40. Chen, J.; Jönsson, P.; Tamura, M.; Gu, Z.; Matsushita, B.; Eklundh, L. A simple method for reconstructing a high-quality NDVI time-series data set based on the Savitzky-Golay filter. Remote Sens. Environ. 2004, 91, 332-344. [CrossRef]

41. Liu, Z.; Wu, C.; Peng, D.; Wang, S.; Gonsamo, A.; Fang, B.; Yuan, W. Improved modeling of gross primary production from a better representation of photosynthetic components in vegetation canopy. Agric. For. Meteorol. 2017, 233, 222-234. [CrossRef]

42. Holben, B.N. Characteristics of maximum-value composite images from temporal AVHRR data. Int. J. Remote Sens. 1986, 7, 1417-1434. [CrossRef]

43. Wu, J.; Gao, X. A gridded daily observation dataset over China region and comparison with the other datasets. Chin. J. Geophys. 2013, 56, 1102-1111. (In Chinese)

44. Hutchinson, M.F.; McKenney, D.W.; Lawrence, K.; Pedlar, J.H.; Hopkinson, R.F.; Milewska, E.; Papadopol, P. Development and testing of Canada-wide interpolated spatial models of daily minimum-maximum temperature and precipitation for 1961-2003. J. Appl. Meteorol. Clim. 2009, 48, 725-741. [CrossRef]

45. Xu, Y.; Gao, X.; Shen, Y.; Xu, C.; Shi, Y.; Giorgi, F. A daily temperature dataset over China and its application in validating a RCM simulation. Adv. Atmos. Sci. 2009, 26, 763-772. [CrossRef]

46. Dee, D.P.; Uppala, S.M.; Simmons, A.J.; Berrisford, P.; Poli, P.; Kobayashi, S.; Andrae, U.; Balmaseda, M.A.; Balsamo, G.; Bauer, P.; et al. The ERA-Interim reanalysis: Configuration and performance of the data assimilation system. Q. J. R. Meteorol. Soc. 2011, 137, 553-597. [CrossRef] 
47. Hao, P.; Tang, H.; Chen, Z.; Liu, Z. Early-season crop mapping using improved artificial immune network (IAIN) and Sentinel data. PeerJ 2018, 6, e5431. [CrossRef] [PubMed]

48. Hao, P.; Wang, L.; Niu, Z.; Aablikim, A.; Huang, N.; Xu, S.; Chen, F. The potential of time series merged from Landsat-5 TM and HJ-1 CCD for crop classification: A case study for Bole and Manas counties in Xinjiang, China. Remote Sens. 2014, 6, 7610-7631. [CrossRef]

49. Liu, J.; Liu, M.; Tian, H.; Zhuang, D.; Zhang, Z.; Zhang, W.; Tang, X.; Deng, X. Spatial and temporal patterns of China's cropland during 1990-2000: An analysis based on Landsat TM data. Remote Sens. Environ. 2005, 98, 442-456. [CrossRef]

50. Liu, J.; Liu, M.; Zhuang, D.; Zhang, Z.; Deng, X. Study on spatial pattern of land-use change in China during 1995-2000. Sci. China Ser. D 2003, 46, 373-384.

51. Liu, Y.; Zhang, Z.; Wang, J. Regional differentiation and comprehensive regionalization scheme of modern agriculture in China. Acta Geogr. Sin. 2018, 73, 203-218. (In Chinese)

52. Evans, J.; Geerken, R. Discrimination between climate and human-induced dryland degradation. J. Arid Environ. 2004, 57, 535-554. [CrossRef]

53. Zhai, P.; Zhang, X.; Wan, H.; Pan, X. Trends in Total Precipitation and Frequency of Daily Precipitation Extremes over China. J. Clim. 2005, 18, 1096-1108. [CrossRef]

54. Gao, T.; Xie, L. Study on progress of the trends and physical causes of extreme precipitation in China during the last 50 years. Adv. Earth Sci. 2014, 29, 577-589. (In Chinese)

55. Sen, P.K. Estimates of the Regression Coefficient Based on Kendall's Tau. J. Am. Stat. Assoc. 1968, 63, 1379-1389. [CrossRef]

56. Cui, L.; Wang, L.; Singh, R.P.; Lai, Z.; Jiang, L.; Yao, R. Association analysis between spatiotemporal variation of vegetation greenness and precipitation/temperature in the Yangtze River Basin (China). Environ. Sci. Pollut. Res. 2018, 25, 21867-21878. [CrossRef] [PubMed]

57. Wang, C.; Zhen, L.; Du, B. Assessment of the impact of China's Sloping Land Conservation Program on regional development in a typical hilly region of the loess plateau-A case study in Guyuan. Environ. Dev. 2017, 21, 66-76.

58. Overland, J.E.; Wang, M. Large-scale atmospheric circulation changes are associated with the recent loss of Arctic sea ice. Tellus A 2010, 62, 1-9. [CrossRef]

59. Trenberth, K.E. Changes in precipitation with climate change. Clim. Res. 2011, 47, 123-138. [CrossRef]

60. Wentz, F.J.; Ricciardulli, L.; Hilburn, K.; Mears, C. How Much More Rain Will Global Warming Bring? Science 2007, 317, 233-235. [CrossRef] [PubMed]

61. Barnett, T.P.; Adam, J.C.; Lettenmaier, D.P. Potential impacts of a warming climate on water availability in snow-dominated regions. Nature 2005, 438, 303-309. [CrossRef] [PubMed]

62. Jia, X.; Shao, M.A.; Zhu, Y.; Luo, Y. Soil moisture decline due to afforestation across the Loess Plateau, China. J. Hydrol. 2017, 546, 113-122. [CrossRef]

63. Liu, Y.; Xiao, J.; Ju, W.; Xu, K.; Zhou, Y.; Zhao, Y. Recent trends in vegetation greenness in China significantly altered annual evapotranspiration and water yield. Environ. Res. Lett. 2016, 11, 094010. [CrossRef]

64. Goswami, B.N.; Venugopal, V.; Sengupta, D.; Madhusoodanan, M.S.; Xavier, P.K. Increasing trend of extreme rain events over India in a warming environment. Science 2006, 314, 1442-1445. [CrossRef] [PubMed]

(C) 2018 by the authors. Licensee MDPI, Basel, Switzerland. This article is an open access article distributed under the terms and conditions of the Creative Commons Attribution (CC BY) license (http:/ / creativecommons.org/licenses/by/4.0/). 